\title{
B.A.D. Codes
}

National Cancer Institute

\section{Source}

National Cancer Institute. B.A.D. Codes. NCI Thesaurus. Code C19182.

Basic, Applied, Development codes. 